\title{
Mucocele del seno maxilar post-traumático
}

\author{
Post-traumatic mucocele of the maxillary sinus
}

E. Charro-Huerga' , J. Ferreras Granado², I. Vázquez Mahía, J.L. López-Cedrún

Resumen: Los mucoceles de los senos paranasales son lesiones benignas pero con un considerable potencial destructivo por la reabsorción ósea que pueden generar. La localización en el seno maxilar es muy poco frecuente así como el origen postraumático. Presentamos el caso de un mucocele de seno maxilar tras 28 años después de un traumatismo facial. Analizamos la etiopatogenia, el diagnóstico y el tratamiento de este tipo de lesiones.

Palabras clave: Mucocele; Seno maxilar; Postraumático.

Recibido: 16.07 .08

Aceptado: 28.01 .09
Abstract: Mucoceles of the paranasal sinuses are benign lesions but they can be destructive because they cause bone resorption. The location in a maxillary sinus and a traumatic origin are uncommon. We report a case of mucocele of the maxillary sinus 28 years after facial trauma. We analyzed the etiopathogenesis, diagnosis, and treatment of this type of lesions.

Key words: Mucocele; Maxillary sinus; Post-trauma.

\footnotetext{
1 Médico Residente.

2 Médico Adjunto.

3 Jefe de Servicio.

Servicio de Cirugía Oral y Maxilofacial del Complejo Hopitalario Universitario de La Coruña. España
}

\section{Correspondencia:}

Esther Charro Huerga

Servicio de Cirugía Oral y Maxilofacial.

Complejo Hospitalario Universitario de La Coruña. España

Hopital Materno Infantil

As Xubias de Arriba 84, 15006

e-mail: esch26@hotmail.com 


\section{Introducción}

Los mucoceles de los senos paranasales se describen como lesiones quísticas, expansivas, tapizadas por epitelio y rellenas de secreciones mucosas, causadas por obstrucción del orificio de drenaje de los senos paranasales. ${ }^{1,2}$ Aunque benignas, son potencialmente destructivas al provocar reabsorción del hueso circundante debido al incremento de presión que producen sobre él. ${ }^{3}$

La localización más frecuente de este tipo de lesiones es el complejo frontoetmoidal, seguido del seno esfenoidal, y es rara su aparición en el seno maxilar. En esta última localización su origen más frecuente son las cirugías previas, siendo los secundarios a fracturas faciales extraordinariamente raros. ${ }^{1}$

Presentamos un caso de mucocele del seno maxilar secundario a una fractura máxilo-malar que el paciente sufrió 28 años antes. Analizamos su etiopatogenia, incidencia, síntomas, diagnóstico y tratamiento.

\section{Caso clínico}

Paciente varón de 55 años remitido a nuestras consultas por el servicio de oftalmología por presentar exoftalmos de globo ocular secundario a tumoración a nivel del seno maxilar derecho.

Como antecedentes el paciente refería una fractura máxilo-malar derecha 28 años antes, en la que se realizó reducción y fijación alámbrica en reborde infraorbitario y arbotante frontomalar.

En la exploración oftalmológica encontramos exoftalmos, distopia vertical del globo ocular y oftalmoplejia en la mirada vertical. Se encontró una falta de proyección del reborde infraorbitario que permitía palpar una masa blanda a dicho nivel.

En la ortopantomografía no se vió relación de la masa con dientes. La TC (Figs. 1 y 2) puso de manifiesto una masa de partes blandas de aproximadamente de $3,5 \mathrm{~cm}$ en seno maxilar derecho, bien delimitada, con remodelación ósea y destrucción del suelo de la órbita y desplazamiento del músculo recto inferior, provocando un exoftalmos secundario.

La intervención quirúrgica consistió en la exéresis de la lesión asociada a la extracción de las fijaciones alámbricas vía subciliar figura

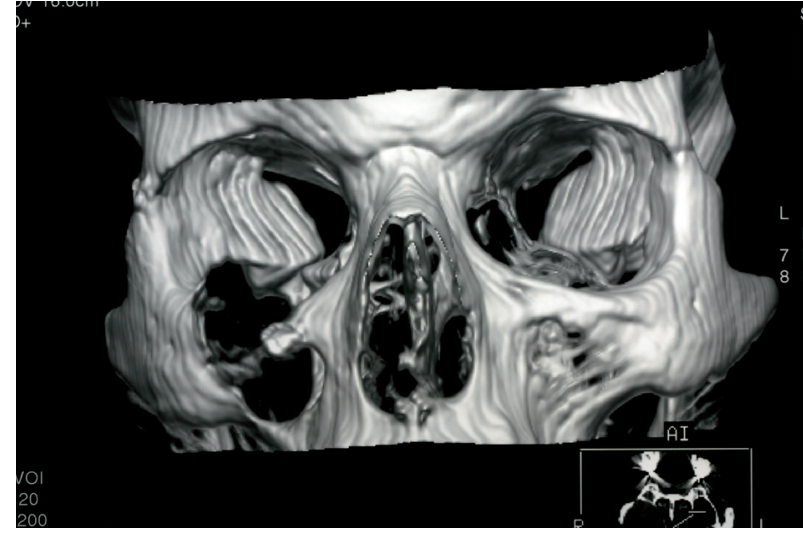

Figura 1. Imagen TC 3D diagnostica. Figure 1. Diagnostic 3D CT image.

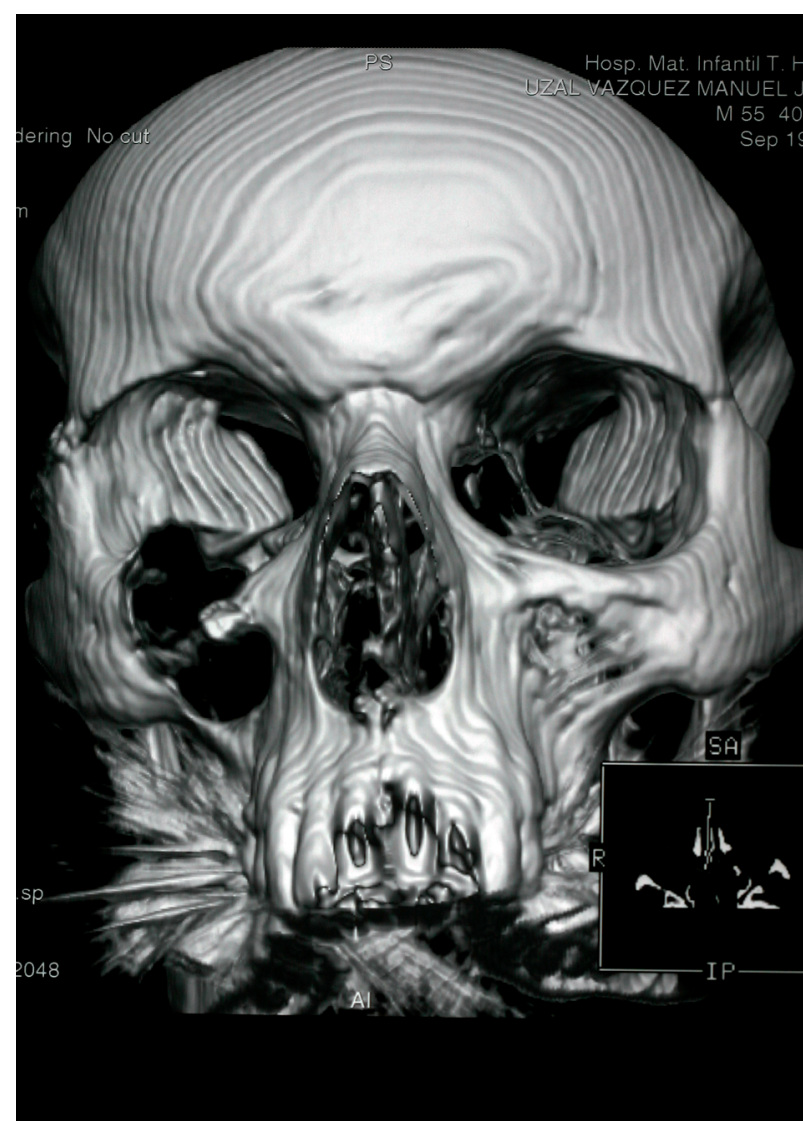

Figura 2. Imagen TC 3D diagnóstica.

Figure 2. Diagnostic 3D CT image.

\section{Introduction}

Mucoceles of the paranasal sinuses are described as cystic, expansive lesions lined by epithelium and filled with mucous secretion as a result of obstruction of the drainage orifice of the paranasal sinuses. ${ }^{1,2}$ Although paranasal mucoceles are benign, they are potentially destructive because they can cause resorption of the surrounding bone by raising the pressure on the bone.

The most frequent location of paranasal mucocele is the fronto-ethmoidal complex, followed by the sphenoid sinus. It occurs only rarely in the maxillary sinus. In the maxillary sinus, the most frequent origin of mucocele is prior surgery; mucocele secondary to facial fracture is extraordinarily rare. ${ }^{1}$

We report a case of mucocele of the maxillary sinus secondary to maxillo-malar fracture that the patient experienced 28 years earlier. We analyzed the etiopathogenesis, incidence, symptoms, diagnosis, and treatment of maxillary mucocele.

\section{Clinical case}

A 55-year-old man was referred to our clinic by the ophthalmology department for exophthalmia secondary to a tumor of the right maxillary sinus.

The patient's history included a right maxillo-malar fracture 28 years earlier, in which reduction and wire fixation of the fracture of the infraorbital rim and frontomalar buttress was performed.

In the ophthalmologic examination we found exophthalmia, vertical dystopia of the ocular globe, and ophthalmoplegia of the vertical gaze. A lack of projection of the infraorbital rim allowed the palpation of a soft mass at this level. 
3), y reconstrucción con prótesis de Medpor (Fig. 4 y 5) del complejo máxilomalar destruido( reborde infraorbitario, suelo de órbita, arbotante frontomalar).

El estudio anatomopatológico confirmó el diagnóstico de mucocele maxilar (Fig. 6).

La evolución del enfermo fue satisfactoria, con buena motilidad ocular, sin diplopia y con un correcto resultado estético (Fig. 7). El seguimiento actual tras tres años continúa siendo satisfactorio sin recidiva ni complicaciones.

\section{Discusión}

Los mucoceles en los senos paranasales son debidos a una obstrucción del ostium, con acumulación mucosa y expansión gradual de la cavidad sinusal.

Existen una serie de factores etiopatogénicos predisponentes predisponentes que podemos dividir en intrínsecos y extrínsecos. ${ }^{2}$ Los factores intrínsecos son aquellos que incrementan la viscosidad del moco, como por ejemplo la fibrosis quística. Como factores extrínsecos se describen pólipos, tumores y desviaciones del tabique nasal, siendo los traumatismos la causa más frecuente de mucocele maxilar, especialmente el trauma quirúrgico y en casos extremadamente infrecuentes las fracturas mediofaciales.

Dentro de estas causas de trauma quirúrgico predisponente se describen extracciones dentales laboriosas, ${ }^{1}$ cirugía ortognática ${ }^{4}$ y Cadwell-Luc. ${ }^{4,5}$

Éste último, está descrito en la literatura como la causa extrínseca más frecuente de mucocele maxilar. Se desarrolla entre 10 y 30 años después del procedimiento y es infrecuente en Europa y EEUU, pero es relativamente frecuente en Japón. ${ }^{1,5}$ Se especula con que esto es debido, probablemente, a la alta prevalencia de sinusitis maxilar, especialmente antes y después de la segunda guerra mundial, que en este periodo era tratada mediante el procedimiento de Cadwell- Luc, ya que no había acceso a antibióticos. ${ }^{1}$ Sin embargo, otros autores como Hasegawa ${ }^{5}$ especulan sobre una predisposición anatómica-racial.

En la literatura revisada encontramos pocos casos secundarios a trauma facial directo sobre el tercio medio facial. $3,6,7$ Es el factor

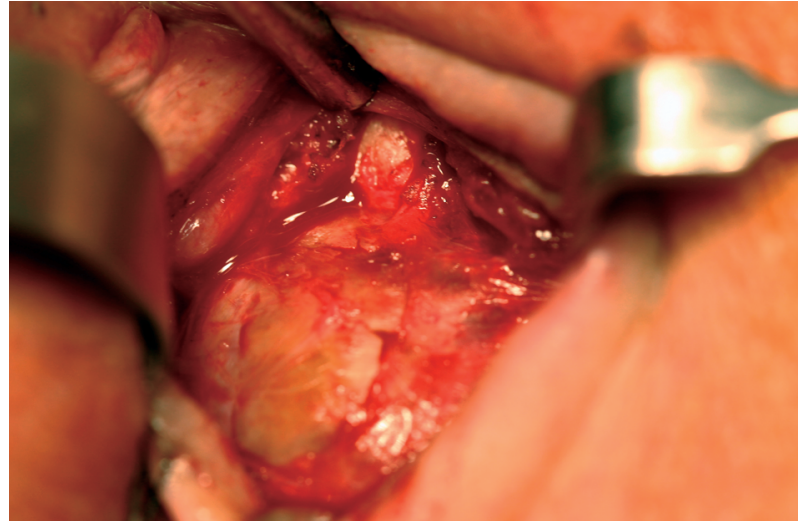

Figura 3. Imagen operatoria de mucocele por abordaje subciliar. Figure 3. Operative image of mucocele via a subciliary approach.

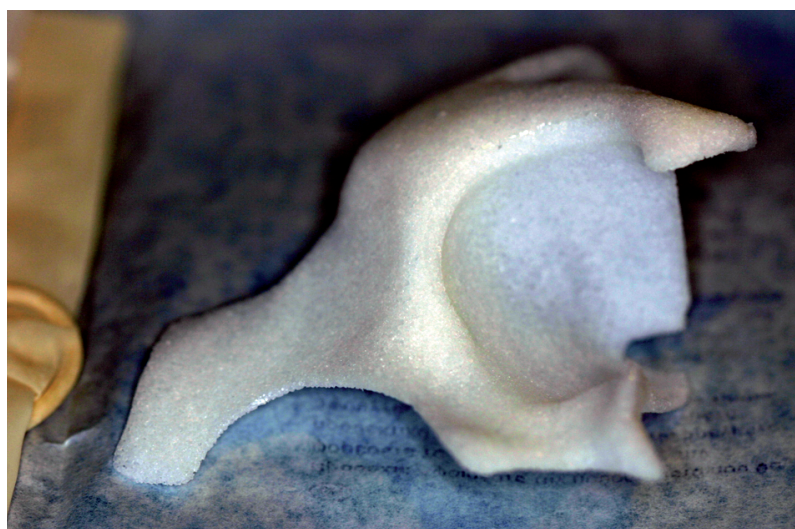

Figura 4. Prótesis de Medpor para reconstrucción del defecto. Figure 4. Medpor prosthesis for reconstructing the defect.

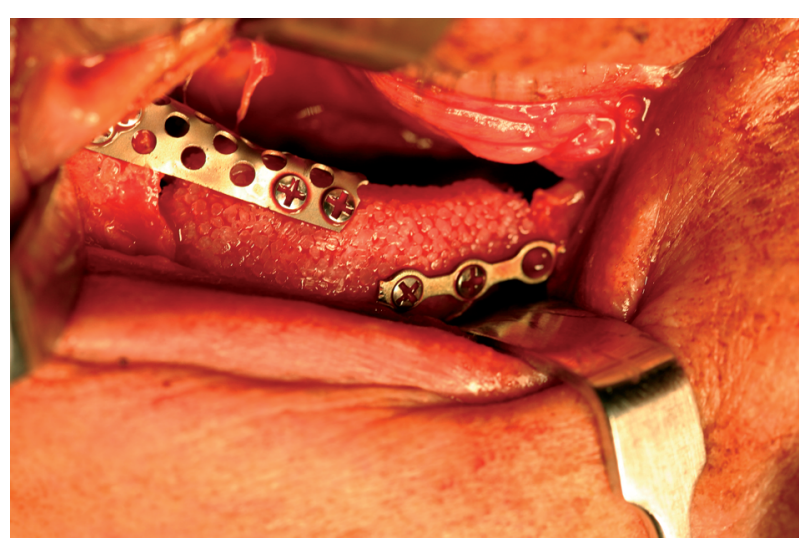

Figura 5. Fijación con placas y tornillos de la prótesis de Medpor en el RIO.

Figure 5. Fixation of the Medpor prosthesis in the region of interest.
In orthopantomography, the relation between the mass and teeth was not evident. CT (Figs. 1 and 2) revealed a well delimited, soft tissue mass approximately $3.5 \mathrm{~cm}$ wide in the right maxillary sinus, with bone remodeling, destruction of the orbital floor, and displacement of the inferior rectus muscle, causing secondary exophthalmia.

The operation consisted of excision of the lesion with extraction of the subciliary fixation wires (Fig. 3) and reconstruction with a Medpor prosthesis (Figs. 4 and 5) of the damaged maxillomalar complex (infraorbital rim, orbital floor, and frontomalar buttress).

Histopathologic study confirmed the diagnosis of maxillary mucocele (Fig. 6).

The evolution of the patient was satisfactory, with good ocular motility, no diplopia, and an acceptable aesthetic result (Fig. 7). At the most recent follow-up visit three years later, the outcome continues to be satisfactory without recurrence or complications.

\section{Discussion}

Mucoceles of the paranasal sinuses are due to ostial obstruction with mucous accumulation and gradual expansion of the sinus cavity. A series of predisposing etiopathogenic factors can be divided into intrinsic and extrinsic. ${ }^{2}$ The intrinsic factors are those that increase mucous viscosity, such as cystic fibrosis. Among the extrinsic factors described are polyps, tumors, and septal deviations. Trauma is the most frequent cause of maxillary mucocele, especially surgical trauma and, in extremely infrequent cases, middle facial fracture. 
predisponente menos común de los descritos. $3,6,8$ En ellos la fisiopatología varía del resto de los mucoceles por cuanto el drenaje del ostium se mantiene íntegro y lo que se produce es un secuestro mucoso de una zona sinusal que se encapsula y pierde su posibilidad de drenaje. ${ }^{3}$

Clínicamente los mucoceles presentan un curso insidioso e indoloro en la mayoría de los $\operatorname{casos}^{3}$ acompañado de abombamiento, deformidad facial y edema geniano. En ocasiones se producen herniaciones hacia las cavidades adyacentes, como la órbita en el caso descrito, pudiendo producir distopia, exoftalmos y diplopia. No obstante, esta afectación orbitaria es infrecuente, Kaneshiro $^{9}$ lo refiere en un 1,4\%, y Hasegawa ${ }^{7}$ en un $7 \%$ de todos los mucoceles postraumáticos maxilares revisados.

Las pruebas de imagen como la proyección de Waters evidenciarán una opacidad del seno parcial o total y junto con una anamnesis detallada nos orientará el diagnóstico. En el TC veremos el adelgazamiento de las paredes maxilares y su erosión, y ausencia de realce de la lesión con la administración de constraste. Nos servirá para hacer diagnóstico diferencial con los quistes de retención y con las lesiones malignas del maxilar respectivamente. ${ }^{1,3}$

Histológicamente, se observa un epitelio de tipo respiratorio tapizando el quiste que en ocasiones ha evolucionado hacia una metaplasia escamosa. ${ }^{1}$

El tratamiento de éstas lesiones es la exéresis simple. En la cirugía los mucoceles se configuran como masas firmes rellenas de fluido que en ocasiones puede ser purulento, hablando entonces de mucopiocele, sin embargo, incluso éstos últimos son generalmente estériles. ${ }^{1}$ Utilizaremos siempre el abordaje más incruento posible, asegurándonos siempre de que nos permita extraer la lesión en su totalidad. La mayoría de los autores ${ }^{10-12}$ confirman las ventajas de un abordaje endoscópico siempre que sea posible, y destacan su escasa invasividad y el escaso tiempo de recuperación; sin embargo su limitación con vistas a la reconstrucción ósea secundaria es importante. ${ }^{3}$

En nuestro caso se hizo éxeresis total, y reconstrucción de la proyección malar y del suelo de la órbita a través de un abordaje subciliar. Se descartó el abordaje endoscópico por la necesidad de reconstrucción del complejo máxilo-malar y el abordaje intraoral para intentar preservar la máxima esterilidad posible y evitar la contaminación con gérmenes de la cavidad oral.

Algunos autores como Hasewaga ${ }^{5}$ no contemplan la necesidad de restaurar la continuidad del suelo de la órbita en caso de
Among the causes of predisposing surgical trauma are difficult tooth extractions, ${ }^{1}$ orthognathic surgery, ${ }^{4}$ and the Cadwell-Luc intervention. 4,5

The Cadwell-Luc intervention is described in the literature as the most common extrinsic cause of maxillary mucocele. It develops 10 to 30 years after the procedure and is infrequent in Europe and the U.S., but relatively common in Japan. ${ }^{1,5}$ It is speculated that this probably is due to the high prevalence of maxillary sinusitis, especially before and after World War II, which at this time was treated by means of the Cadwell-Luc procedure due to the unavailability of antibiotics. ${ }^{1}$ Nevertheless, authors like Hasegawa ${ }^{5}$ have speculated about a racial anatomic predisposition.

In the literature reviewed, we found few cases secondary to direct trauma to the middle third of the face, ${ }^{3,6,7}$ It is the least common of the predisposing factors described. $3,6,8$ In these patients the pathophysiology varies with respect to other mucoceles because ostial drainage remains patent. Mucous sequestration of a sinus zone occurs, which becomes encapsulated and stops draining. ${ }^{3}$

Clinically, mucoceles have an insidious and painless course in most cases, ${ }^{3}$ accompanied by swelling, facial deformity, and chin edema. Sometimes, herniation into the adjacent cavities occurs, such as the orbit in the case reported, which may cause dystopia, exophthalmia, and diplopia. However, orbital involvement is infrequent. Kaneshiro ${ }^{9}$ reports it in $1.4 \%$ and Hasegawa 7 in $7 \%$ of all post-traumatic maxillary mucoceles reviewed.

Imaging studies, such as the Waters projection will reveal partial or total opacity of the sinus. In conjunction with a detailed interview, this will lead to the diagnosis. CT shows thinning and erosion of the maxillary walls, together with the absence of enhancement of the lesion after contrast is administered. This will serve us in the differential diagnosis with retention cysts and malignant lesions of the maxilla, respectively. ${ }^{1,3}$

Histologically, a respiratory type epithelium lining the cyst is observed that sometimes has evolved to squamouscell metaplasia. ${ }^{1}$ 
que esté afectada, sin embargo nosotros consideramos importante la reconstrucción para obtener un buen resultado estético función de la motilidad ocular.

\section{Bibliografía}

1. Gardner D, Gullane P. Mucoceles of the maxillary sinus. Oral Surg Med Oral Pathol 1986;62:538-43.

2. Zizmor, Novek, Chapnik JS. Mucocele of the paranasal sinuses. Cn J Otolaryngol 1974; Suppl 1.

3. Hasegawa M, Kuroishikawa Y. Protusion of postoperative maxillary sinus mucocele into the orbit: case reports. ENT Journal 1993;72:11.

4. Thio $D, y$ cols. Maxillary sinus mucocele presenting as a late complication of a maxillary advancement procedure. The Journal of Laryngology \& Otology May 2003;117:402-3.

5. Billing KJ, Davis G, Selva D, Wilscek G, Mitchell R. Post-traumatic maxillary sinus mucocele. Ophthalmic Surgery, Lasers and Imaging 2004;35:152-5.

6. Kaltreider SA, Dortzbach RK. Destructive cysts of the maxillary sinus affecting the orbit. Arch Ophthalmol 1988;106:1398-402.

7. Hassegawa M, Saito Y, Watanabe I, Kern EB. Postoperative mucoceles of the maxillary sinus. Rhinology 1979;17:253-6.

8. Hayasaka S, Shibasaki H, Sekimoto M, Setogawa T, Wakutani T. Ophtalmic complications in patients with paranasal sinus mucopyoceles. Ophtalmologica 1991;203:57-63.

9. Kaneshiro S, Nakajima T, Yoshikawa Y, et al. The postoperative mucoceles of the maxillary cyst: report of the 71 cases. J Oral Surg 1981;39:191-8.

10. Dispenza C, Saraniti C, Dispenza F. Endoscopic treatmente of maxillary sinus mucocele. Acta otorhinolaryngol Ital 2004;24:292-6.

11. Bockmuhl U, Kratzsch B, Benda K, Draf W. Surgery for paranasal sinus mucoceles: efficacy of endonasal micro-endoscopic management and long-term results of 185 patients. Rhinology 2006;44:62-7.

12. Bockmuhl U, Kratzsch B, Benda K, Draf W. Paranasal sinus mucoceles:surgical management and long term results. Laryngorhinootologie 2005;84:892-8.
The treatment of these lesions is simple exeresis. In surgery, mucoceles are firm masses filled with fluid that sometimes can be purulent. In this case we refer to it as mucopyocele, but it is generally sterile.' We should always use the least invasive approach possible and ensure that the entire lesion is removed. Most authors ${ }^{10-12}$ confirm the advantages of an endoscopic approach whenever possible, and emphasize its scant invasiveness and short recovery time; however, its limitation with respect to secondary bone reconstruction is important. ${ }^{3}$

In our case, total exeresis was performed and the malar projection and floor of the orbit were reconstructed through a subciliary approach. The endoscopic approach was ruled out due to the need for reconstruction of the maxillo-malar complex and the intraoral approach was ruled out to preserve the maximum sterility possible and to avoid contamination with germs from the oral cavity.

Some authors, such as Hasewaga, ${ }^{5}$ do not think that the continuity of the orbital floor has to be restored if it is affected. However, we think that reconstruction is important to obtain good aesthetic and functional ocular motility result. 